\title{
CORE learning model: Its effectiveness towards students' creative thinking
}

\author{
Antomi Saregar ${ }^{1}$, Umi Nur Cahyanti ${ }^{2}$, Misbah $^{3}$, Nur Endah Susilowati $^{4}$, Adyt Anugrah ${ }^{5}$, \\ Nurlaela Muhammad ${ }^{6}$ \\ 1,2,4,5 Department of Physics Education, Universitas Islam Negeri Raden Intan Lampung, Indonesia \\ ${ }^{3}$ Department of Physics Education, Universitas Lambung Mangkurat, Indonesia \\ ${ }^{6}$ Department of Physics Education, Universitas Khairun, Indonesia
}

\section{Article Info}

Article history:

Received Jun 25, 2020

Revised Dec 19, 2020

Accepted Jan 27, 2021

\section{Keywords:}

CORE learning model

Creative thinking

Sound waves

\begin{abstract}
The research has been carried out at the Islamic junior high school of East Lampung to determine the effectiveness of the Connecting, Organizing, Reflecting, and Extending (CORE) learning model on students' creative thinking skills on sound waves topic. The research method used was a quasiexperimental design with Non-Equivalent Control Group Design. Data on creative thinking skill were collected using essay test instrument. This research was conducted on the eighth-grade students of an Islamic senior high school in East Lampung with a sample of 60 students taken by using purposive sampling technique. Based on the Effect Size test, the effectiveness value of the CORE model on students' creative thinking skills are 0.48 which is in the medium category. These results prove that the CORE learning model is effective in enhancing students' creative thinking skills on sound wave material. This study also provides a storyboard on how to apply an effective CORE model to improve students' creative thinking abilities.
\end{abstract}

This is an open access article under the CC BY-SA license.

\section{Corresponding Author:}

Antomi Saregar

Department of Physics Education

Universitas Islam Negeri Raden Intan Lampung

J1. Letnan Kolonel H. Endro Suratmin, Kota Bandar Lampung, 35131, Indonesia

Email: antomisaregar@ radenintan.ac.id

\section{INTRODUCTION}

Creative thinking is an ability that must be possessed by individuals in this digitalization era [1-3]. Because in this era, technology is developing rapidly, including in the field of education, so that global competition is very tight [4-7]. To ensure individuals are not eliminated in this competition, creative thinking is needed. However, many studies report that there are still many students in Indonesia who have low creative thinking skills [8-10].

Several studies have also revealed that learning in several schools in Indonesia has not been able to develop students' creative thinking skills optimally, as revealed in Prianto's research which stated that students of SMP N 1 Jepara, East Java often had difficulty in completing questions presented in the form of stories and they are not trained to solve problems in various forms [11]. As the result, reasoning ability and logical thinking are less developed. Other research conducted by Putra, et al. also revealed that in Cimahi Middle School, the student' low concept understanding hindered their creative thinking processes [12]. Akmalia, et al. and Wahyudi also revealed that the lack of learning experience resulting in low creative thinking abilities [13, 14]. According to Mawarni and Angraini, MTs N Model Makassar (Junior High School 
in Makassar, Indonesia) students were less trained to think, to find ideas, or to answer a problem, so the students' creative thinking skills are categorized as low [15].

This creative thinking problem also occurred at the Islamic junior high school in East Lampung. Based on the results of the pre-survey and interviews with teachers, it was known that there were problems with students' creative thinking abilities. For instance, students had not been able to come up with more than one idea in answering questions, which means, students had problems in the aspect of thinking smoothly. Students also had not been able to determine their ways to solve a problem given in learning (not able to think flexibly). In the original aspect, this can be seen from the difficulty in generating varied ideas, interpreting images, and giving different perspectives to the theories. In the aspect of detailed thinking, students had not been able to describe a reason for the solution or problem in detail and had not been able to develop the ideas of others. In the aspect of thinking elaboration, students also had not been able to conclude good learning.

The statements were supported by the pre-research creative thinking test. Researchers used the description test to find out the percentage of creative thinking abilities possessed by students. According to the test results, it is known that creative thinking abilities of Islamic junior high school of East Lampung were still at a low level. Several studies have revealed solutions to overcome the students' creative thinking abilities problems. One of the solutions is through the application of certain learning models in which steps can train students to get used to thinking creatively. Some learning models that have been proven effective to improve the creative thinking skill is: 1) Problem-based learning model; by accustoming students to find out their answers to problems related to theory. The problem-based learning model has been proven to have a positive effect on students' creative thinking abilities [16-21]; 2) Blended Learning model combined with Project-based Learning has been proven to be able to improve students' creative thinking abilities seen from the increased ability in each indicator of creative thinking [22]; 3) Connecting, Organizing, Reflecting, and Extending model (CORE) has been proven effective in improving higher-order thinking skills [23].

Based on several studies, it has been known that CORE was proven capable in increasing students' mathematical connections $[24,25]$ and showing a positive and significant influence on divergent thinking [26]. The CORE learning model combines four important constructivist elements, namely: connecting students' knowledge, organizing new knowledge, providing opportunities for students to reflect on it, and allowing students to expand the knowledge [27]. A research by Maftukhah also stated that CORE learning model has been proven capable in improving students' creative thinking skills [28].

Previous research has proven that the CORE learning model has been proven effective in upgrading students' creative thinking skill, but, in Maftukhah research [28] (and even in other researches that used CORE learning model) has not explained in detail about the application of every stage of CORE learning model (empiric experience), so, many teachers, researchers, and education practitioners are curious about how each stage in the CORE learning model can influence each indicator on creative thinking skill. This research is here to fill this gap, besides to overcome the problem of creative thinking that occurred at the Islamic junior high school in East Lampung, it also provides a storyboard that describe how to apply the appropriate CORE model to improve the creative thinking skill, so, it can be a guide for teachers who are interested to apply this model in the class learning.

\section{RESEARCH METHOD}

This research is a quasi-experiment with a non-equivalent control group design. The experimental group and the control group were not chosen haphazardly, but rather purposively (using purposive sampling technique). We choose these two classes as the because: 1) These two classes were not superior classes; 2) These two classes were taught by the same physics teacher. The treatment lasted for four weeks and started by providing an initial test in the first week (in the same day), this initial test aimed to determine the profile of students' initial creative thinking abilities. Then, both were given the treatments; the experimental group used the CORE learning model and the control group used the scientific approach. It should be noted that apart from the differences in the learning model, there was no other different treatment. The assignments, media, and topics taught were the same. After that, a post-test was given as the reference data to see the effectiveness of each treatment of creative thinking abilities.

The population in this study were students of the East Lampung Unggulan Islamic Junior High School. The sample used was class VIII A with a total of 30 students as an experimental class and VIII B with a total of 30 students as a control class. These samples were tested with the Normality and Homogeneity test using SPSS 25 software with the provision sig. values $>0.05$. Based on the results of the normality test, the experimental class reached a significance value of 0.064 and the experimental class reached a significance value of 0.126 . So, the two samples are normally distributed (reached more than 0.05 significant 
value). Based on the homogeneity test, a significance value of 0.530 was obtained, this meant that the samples came from the same population (homogeneous).

The research instruments were an essay test to measure students' creative thinking abilities and an observation sheet to determine the feasibility of the model. Before the test was administered, it was tested to find out the level of validity, reliability, level of difficulty, and discriminating index. From validity and reliability test, this instrument was stated valid and reliable. Besides, hypothesis testing in this study was not only limited to the Gain test, but also used the Effect Size test. The Effect Size test was used to see the increase in the results of the pre-test and post-test and ensure that the increase was the influence of the research variable (not due to external factors). An overview of the steps of the research is presented in the Figure 1.

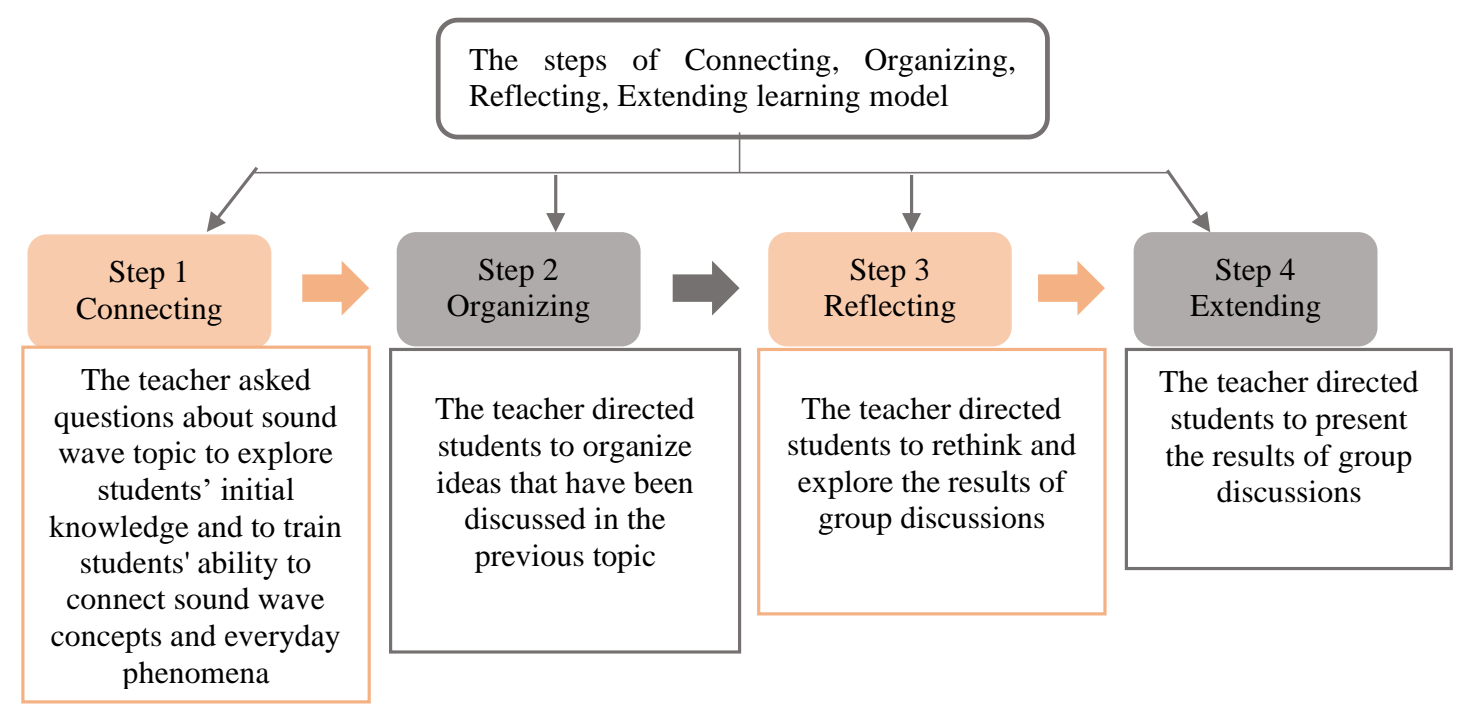

Figure 1. The steps of connecting, organizing, reflecting, extending learning model

\section{RESULTS AND DISCUSSION}

The data analysis of students' abilities consisted of data analysis skills before (pre-test) and after (post-test) learning. The pre-test and post-test data analyses are presented in Table 1. Based on the data, it is recognized that the average score of the pre-test in the experimental class was greater than the average score in the control class. In the pre-test, the experimental class got an average score of 47 while the control class got an average score of 44 . The average posttest score of the experimental class was 79 and the average score of the control class was 69. A comparison of the increase in pre-test post-test scores between the two classes is presented in Figure 2.

Table 1. Students' creative thinking abilities data

\begin{tabular}{ccccc}
\hline \multirow{2}{*}{ Data } & \multicolumn{2}{c}{ Experimental class } & \multicolumn{2}{c}{ Control class } \\
& Pre-test & Post-test & Pre-test & Post-test \\
\hline Mean & 47 & 75 & 44 & 69 \\
Min score & 37 & 67 & 33 & 60 \\
Max score & 58 & 83 & 53 & 78 \\
\hline
\end{tabular}

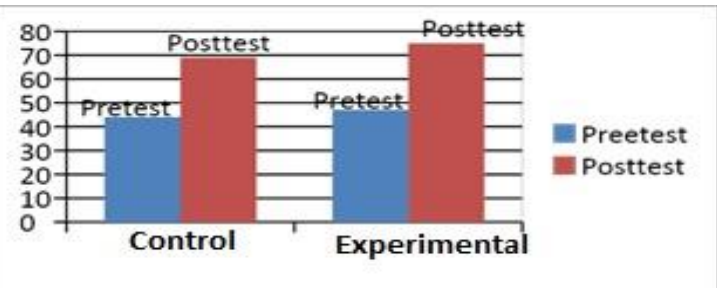

Figure 2. Comparison graph of pretest and posttest score increase 
In Figure 2, it is seen that not only the average post-test score of the experimental class is greater than the average post-test score of the control class, but also the increase in the scores of the pre-test to the post-test in experimental class is greater than the increase in the control class. Again, the increase in students' creative thinking scores can be distinguished from their gain scores. The gain score of creative thinking is presented in Table 2 .

Table 2. Gain score of creative thinking abilities

\begin{tabular}{cccc}
\hline \multirow{2}{*}{ Data } & \multicolumn{2}{c}{ Gain score } & \multirow{2}{*}{ Criteria } \\
\hline Creative thinking & 0.48 & 0.34 & Moderate \\
\hline
\end{tabular}

Table 2 states that the increase in score in the experimental class is greater than the control class that was indicated by the gain score of the two classes. The gain score of the creative thinking of the experimental class was 0.48 and the gain value of the control class was 0.34 which is categorized in the moderate criteria. The difference in the increase in the average gain score between the experimental class and the control class shows the effectiveness of the CORE model toward students' creative thinking.

The CORE learning model is said to be effective if after using this model, there is an increase in the students' creative thinking abilities. The CORE learning model is effective in improving students' creative thinking abilities based on the Effect Size test as displayed in Table 3. Table 3 shows that the effect size of creative thinking is 0.57 which is included in the Moderate category. This shows that the CORE model really gave an impact on students' creative thinking in Physics with a fairly high category. This happened because the steps in the CORE learning model triggered students to think fluently, think flexibly, think originally, and think elaborately. More about this is explained in Table 4.

Table 3. Test results of effect size test

\begin{tabular}{cccl}
\hline Variable & Effect size & Standard deviation & Category \\
\hline Creative thinking & 0.57 & 167.27 & Moderate \\
\hline
\end{tabular}

Table 4. Storyboard of CORE model based on creative thinking

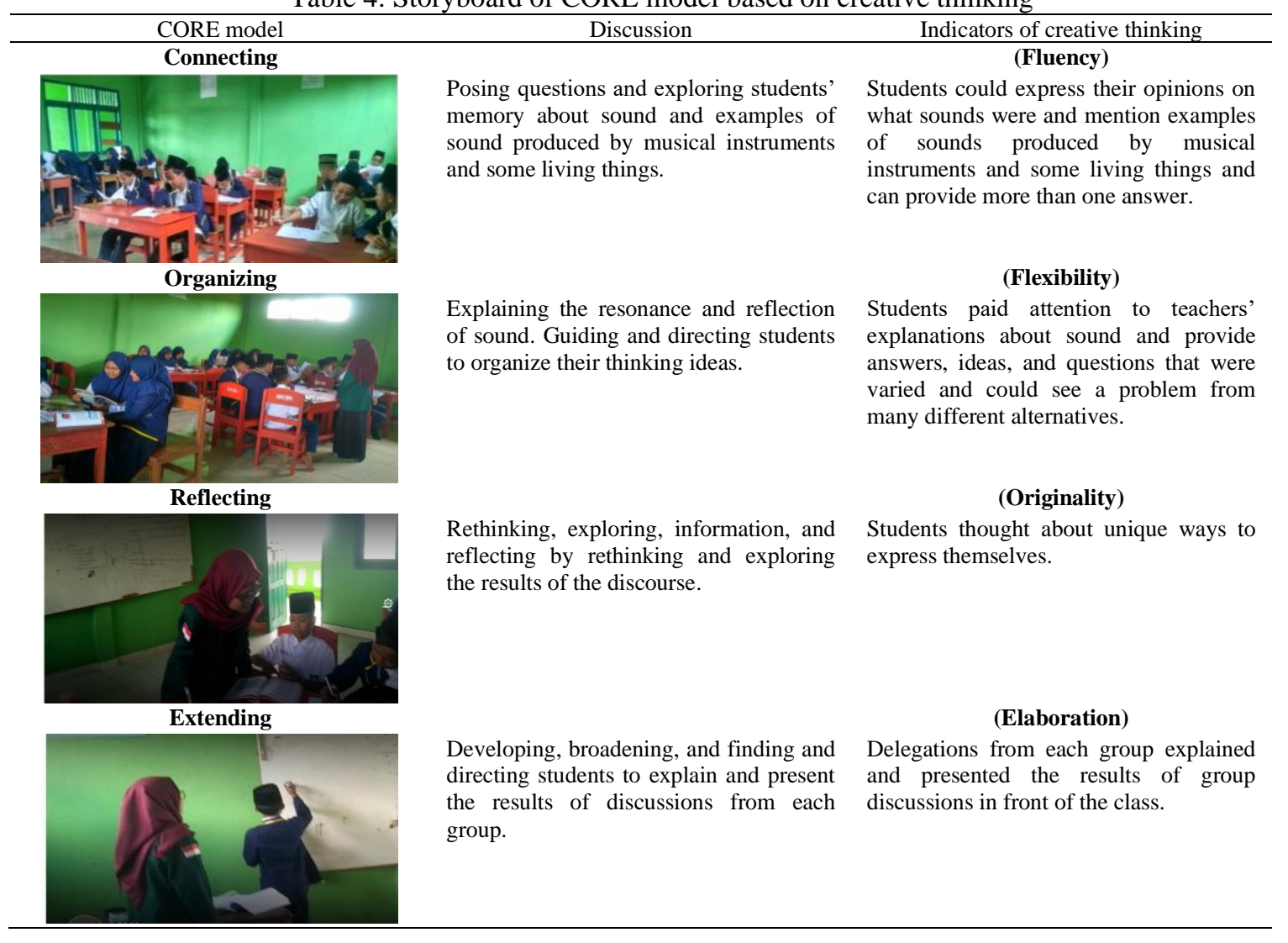

Int J Eval \& Res Educ, Vol. 10, No. 1, March 2021: 35 - 41 
The creative thinking ability is a person's skill for new ideas that can be applied to deal with problems [29]. Based on Table 3 the results of hypothesis testing using the Effect Size test can be assumed that the CORE model was effective in fostering students' creative thinking. This was due to learning by applying the CORE model, the students were required to think creatively based on the information obtained. During the activities, they connected old and new concepts, remember old information, and use new information. Through this learning, students can expand their knowledge during the learning process. In learning by applying the scientific approach, the students got more information from teachers, so that in learning, they were less trained in creative thinking. The finding of this research was in line with the earlier study which stated that the biggest aspect that played a role in students' problem solving skills was the aspect of understanding of creative thinking skill [16].

The previous research related to CORE learning models states that it could improve students' understanding of concepts [30], had a constructive effect on the skill of critical thinking of students [31], and improved students' creative thinking skills [32]. In the learning practice, the CORE model was studentcentered where students looked for solutions and build their knowledge. This provided a different experience so that students could improve their problem-solving abilities, especially in creative thinking abilities. Therefore, CORE learning model can also train students to get used to collaborating in group learning. Table 5 showed the results of students' answers in the pre-test and post-test of two sample classes. Table 5 will help us to see differences in students' answers before and after treatment.

Table 5. Sample answers from control and experimental classes (Post-test)

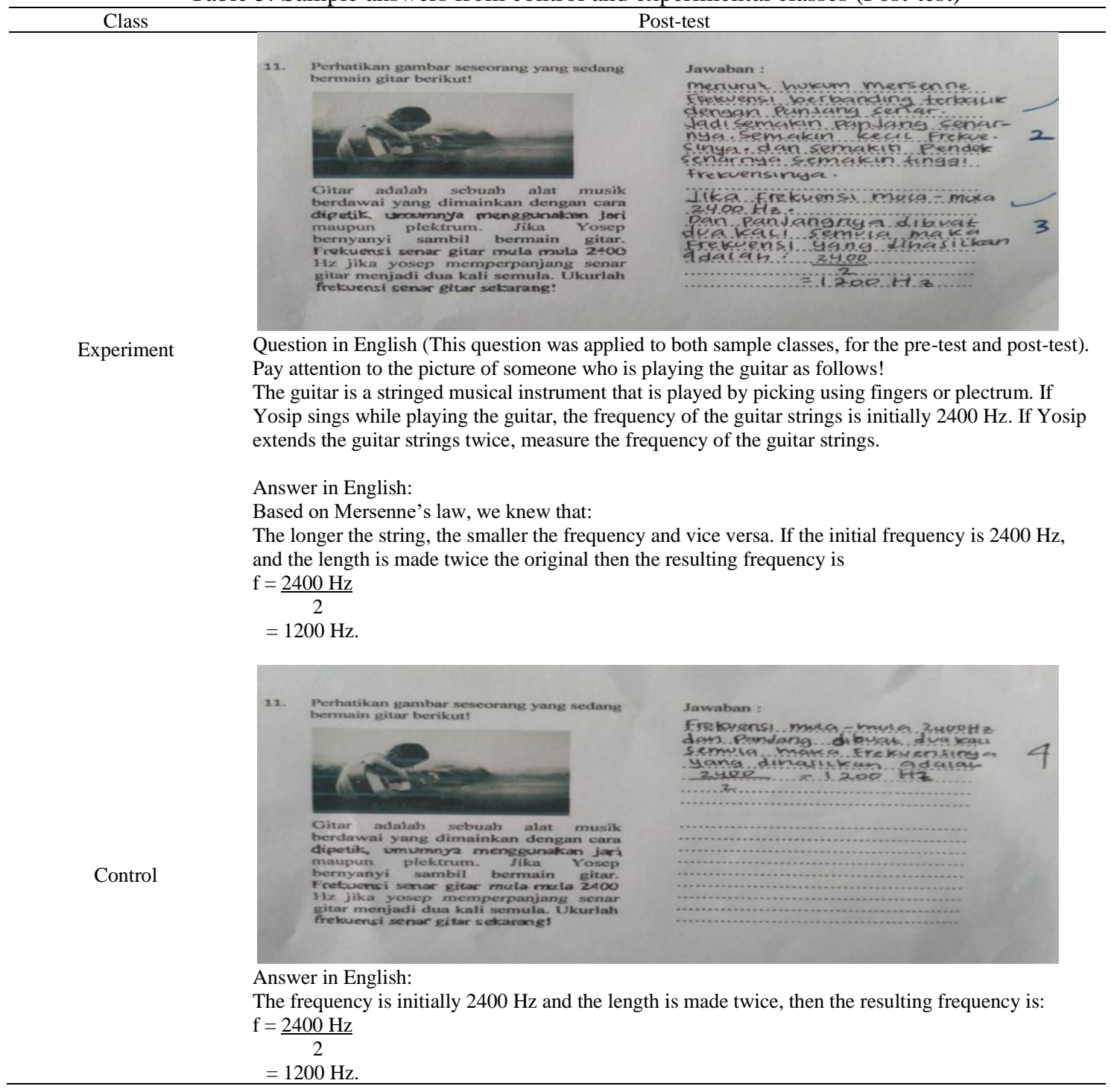


In Table 5, it can be seen the difference in answers and compare the answers of each student in the control class and the experimental class. Before the learning model was applied (before treatment was given), most students solved problems in the pretest in the wrong way, this happened because the students were wrong in analyzing the questions, so they gave the wrong answers. After providing treatment by applying two different learning models in two sample classes, it observed an upturn in students' creative thinking in solving problems. However, experimental class students were able to provide more detailed and structured answers than answers provided by students in the control class.

While solving problems in the post-test, there were two students from each sample class who answered the questions appropriately. Anyhow, there were discrepancies in the completion of answers by students who learn with the CORE learning model with students who do not learn with the CORE learning model. This difference was striking from the way students identify problems. A student from the experimental class explained "why frequency is inversely proportional to the length of the strings" by confirming the reason for the detailed answer, namely: the longer the guitar strings, the smaller the frequency and vice versa. It showed that students had their assessment of a problem presented and can draw conclusions and present answers well.

Although the answers were both correct, students were truly able to describe solutions in a systematic and detailed manner and which students were only able to answer improvised questions. Thus, the answers from the experimental class students proved to be more systematic, detailed, and included the translation of the right concepts compared with the answers from the students in the control class.

Applying the CORE model in learning could train students to think fluently, flexibly, original, and elaboratively. Because the combination of the Connecting-Organizing-Reflecting-Extending steps produces great performance when applied optimally. Based on the observations during research, the connecting step could improve students' skills to think fluently. At this step, students were able to connect many concepts and knowledge, this is in accordance with previous research conducted by Yulianto, et al. which stated that the CORE learning model was able to improve mathematical connection skill [24]. At the Organizing step, students were given information about a concept and hold discussions with their group-mates. So that students could see a concept from various points of view, this activity could improve their flexible thinking skills. At the Reflecting step, students reflected and thought about a concept in depth, and at the Extending step, students presented the results of the discussion and their thoughts, so, these steps will practice their original thinking and elaborate thinking skills. The results of this study were supported by Arifah's research which revealed that CORE learning model had a positive effect on students' creative thinking skills [32]. Before starting a learning process, teachers have to prepare an overview of the benefits of learning the material to be learned in daily life. So, the teacher will indirectly get used to thinking creatively to prepare images that can trigger student curiosity.

\section{CONCLUSION}

Based on the findings of the research, it can be concluded that the CORE learning model is efficient in increasing students' creative thinking abilities. This was proven by the results of the effect size test which stated that the effectiveness value of the CORE model for creative thinking skill was 0.57 , in the moderate category. So, the CORE model gave a quite high effect on students' creative thinking in physics.

\section{REFERENCES}

[1] K. W. Wardika, K. U. Ariawan and P. S. Arsa, "Application of the CORE Model (Connecting, Organizing, Reflecting, Extending) to Improve the Results of Learning Activities in Computer Assembly Class XTJKJ2 (in Bahasa),"J. Pendidik. Tek. Elektro, vol. 6, no. 3, pp. 127-136, 2017.

[2] D. Wahyuni, "Improving Teacher Competence Towards the 4.0 Revolutionary Era (in Bahasa)," Kajian Singkat Terhadap Isu Aktual Dan Strategis, vol. 10, no. 24, 2018. [Online]. Available: https://berkas.dpr.go.id/puslit/files/info_singkat/Info\%20Singkat-X-24-II-P3DI-Desember-2018-218.pdf

[3] A. Khoiri, Nulngafan, W. Sunarno, and Sajidan, "How is Students' Creative Thinking Skills? An Ethnoscience Learning Implementation,” J. Ilm. Pendidik. Fis. Al-BiRuNi, vol. 8, no. 2, pp. 153-163, 2019.

[4] I. Syafei, A. Saregar, Hairul, A. Hahir, P. M. Sari, and A. Anugrah, "E-learning with STEM-Based Schoology on Static Fluid Material," J. Phys. Conf. Ser., vol. 1457, no. 1, pp. 1-9, 2020.

[5] A. Saregar, G. Giyoto, F. Ariyani, T. I. Pawe, A. Pricilia, and D. Astriawan, "How to Design Physics Posters Learning Media with Islamic Values in Developing Learning Motivation and Student Character?" J. Phys. Conf. Ser., vol. 1155, no. 1, pp. 1-9, 2019.

[6] P. Nuangchalerm, et al., "Environment-Friendly Education as A Solution to Against Global Warming: A Case Study at Sekolah Alam Lampung, Indonesia," J. Educ. Gift. Young Sci., vol. 7, no. 2, pp. 87-97, 2019. 
[7] A. Thahir, C. Anwar, A. Saregar, L. Choiriah, F. Susanti, and A. Pricilia, "The Effectiveness of STEM Learning: Scientific Attitudes and Students' Conceptual Understanding,” J. Phys. Conf. Ser., vol. 1467, no. 1, 2020.

[8] H. T. Damayanti, "Mathematical Creative Thinking Ability of Junior High School Students in Solving Open-Ended Problem," J. Res. and Advances in Math. Edu., vol. 3, no. 1, pp. 36-45, 2018.

[9] R. D. Pratiwi, Ashadi, Sukarmin, and D. Harjunowibowo, "Students' Creative Thinking Skills on Heat Phenomena using Pogil Learning Model,” J. Ilm. Pendidik. Fis. Al-BiRuNi, vol. 08, no. 2, pp. 221-231, 2019.

[10] A. Malik, Y. Nuraeni, and A. Samsudin, "Creative Thinking Skills of Students on Harmonic Vibration using Model Student Facilitator And Explaining (SFAE)," J. Ilm. Pendidik. Fis. Al-BiRuNi, vol. 8, no. 1, pp. 77-88, 2019.

[11] A. Prianto, Subanji, and I. M. Sulandra, "Creative Thinking in RME Learning (in Bahasa)," J. Pendidik. Teor. Penelitian, dan Pengemb., vol. 1, no. 7, pp. 1442-1448, 2016.

[12] H. D. Putra, A. M. Akhdiyat, E. P. Setiany, and M. Andiarani, "Mathematical Creative Thinking Ability of Junior High School Students in Cimahi (in Bahasa)," Kreano, J. Mat. Kreat., vol. 9, no. 1, pp. 47-53, 2018.

[13] N. N. Akmalia, H. Pujiastuti, and Y. Setiani, "Identification of Mathematical Creative Thinking Step through the Application of Problem Based Learning Model with Problem Submission Task (in Bahasa)," J. Penelit. pembelajaran Mat., vol. 9, no. 2, pp. 183-193, 2016.

[14] Wahyudi, "Scaffolding according to Learning Style as an Effort to Improve Mathematical Creative Thinking Ability (in Bahasa)," J. Pendidik. Dasar dan Pembelajaran, vol. 7, no. 2, pp. 144-157, 2017.

[15] Kartini, "Effectiveness of Synectic Learning Models towards Creative Thinking Ability and Student Exploration (in Bahasa)," J. Pendidik. Fis., vol. 3, no. 1, pp. 27-31, 2015.

[16] F. Aditia and S. Damayanti, "The Effect of Problem Based Learning Model on Students' Creative Thinking Ability in Social Studies Learning at SDN Ngadirejo, Kediri City (in Bahasa)," J. Pendidik. Dasar Nusant., vol. 3, no. 2, pp. 175-188, 2018.

[17] A. Purnamaningrum, S. Dwiastuti, R. M. Probosari, and Noviawati, "Improvement of Creative Thinking Ability through Problem Based Learning (PBL) in Biology Learning for Class X-10 Students of SMA Negeri 3 Surakarta academic year 2011/2012 (in Bahasa)," J. Pend. Biology., vol. 4, no. 3, pp. 39-51, 2012.

[18] M. Diantoro and J. R. Bartlolona, "Influence of Problem Based Learning Model on Student Creative Thinking on Elasticity Topics A Material,” J. Pendidik. Fisik. Indo., vol. 14, no. 1, pp. 32-39, 2018.

[19] A. Elizabeth and M. M. Sigahitong, "The Influence of the Problem Based Learning Model on Students' Creative Thinking Ability (in Bahasa)," Jurnal Pengkaj. Ilmu dan Pembelajaran MIPA IKIP Mataram, vol. 6, no. 2, pp. 66-76, 2018.

[20] W. Khoiri, Rochmad, and A. N. Cahyono, "Problem based learning assisted with multimedia in mathematics learning to improve creative thinking ability (in Bahasa)," Unnes J. Math. Educ., vol. 2, no. 1, pp. 114-121, 2013.

[21] M. F. Rezky, "Effect of Problem Based Learning (PBL) Models of Critical Thinking Ability Students on The Early Mathematics Ability," J. Pend. Fisika, vol. 4, no. 7, pp. 361-374, 2016.

[22] R. A. Candra, A. T. Prasetya, and R. Hartati, "Analysis of Students' Creative Thinking Ability through Blended Project-Learning Application (in Bahasa),” J. Inov. Pendidik. Kim., vol. 13, no. 2, pp. 2437-2446, 2019.

[23] C. Chistella and H. Soekamto, "A comparison between generative learning model and CORE learning model: The influence on learners' hingher order thingking skill," IOSR J. Res. Method Educ., vol. 7, no. 2, pp. 48-52, 2017.

[24] A. R. Yulianto, Rochmad, and N. K. Dwidayat, "Efektivenes of Core Model with Scaffolding to Improve The Mathematical Connection Skill' Universitas Negeri Semarang," J. Prim. Educ., vol. 9, no. 1, pp. 1-7, 2019.

[25] H. P. Nanmumpuni and E. Listiyani, "The Comparison of the Effectiveness of the CORE and STAD Learning Models Viewed from the ability of Connections and Mathematical Reasoning (in Bahasa)," J. Pendidik. Mat., vol. 6, no. 6, pp. 43-54, 2017.

[26] P. Y. Artasari, N. W. Arini, and I. N. Wirya, "The Effect of Connecting Organizing Reflecting Extending (CORE) Learning Model on the Divergent Ability of Class IV Students in Social Studies Subjects (in Bahasa)," MIMBAR PGSD Undiksha, vol. 1, no. 1, 2016.

[27] M. S. Curwen, R. G. Miller, K. A. Wheite-Smith, and R. C. Calfe, "Increasing Teachers' Metacongnition Develops Students' Higher Learning during Content Area Literacy Instruction,” J. Teach. Edication, vol. 19, no. 2, pp. $128-151,2010$.

[28] N. A. Maftukhah, K Nurhalim, and Isnarto, "Creative Thinking Ability in Connecting Organizing Reflecting Extending Learning Model Viewed from Emotional Intelligence (in Bahasa)," J. Prim. Educ., vol. 6, no. 3, pp. 267-276, 2017.

[29] L. W. Anderson and D. R. Krathwohl, Framework, Platform for Learning and Assessment (in Bahasa). Yogyakarta: Pustaka Belajar, 2010.

[30] M. D. P. Subarjo, I. W. R. Sudhita, and I. M. Suarjana, "The Influence of the CORE Model on the Understanding of Science Concepts in Class V Students in Cluster I Nakula, Negara District, Jembrana Regency (in Bahasa)," $J$. Mimb. PGSD Univ. Pendidik. Ganesha, vol. 2, no. 1, 2014.

[31] K. Udyani, I Nyoman Gita, and I. P. Suryawan, "The Effect of CORE-Based Open Assisted Learning Model on Students' Mathematical Critical Thinking Skills (in Bahasa)," J. Pendidik. Mat. Undiksha, vol. 9, no. 1, pp. 54-62, 2018.

[32] Y. N. Arifah, Rochmad, and Sugiman, "The Effect of CORE Learning Model Assisted by Case Study Strategies on Creative Thinking Ability of Junior High School Students (in Bahasa)," Unnes J. Math. Educ., vol. 5, no. 2, 2016. 